\title{
An Analysis of Grammar Teaching in Secondary School in Terms of Success, Attitude and Teachers 'Views*
}

\section{Ayşegül Kayar ${ }^{1}$ Fatih Veyis ${ }^{2 \rtimes}$}

Bayburt University, Educational Faculty, Turkey.

'Atatürk University, Educational Faculty of Kâzım Karabekir, Turkey.

Email:fatih.vevis@atauni.edu.tr.
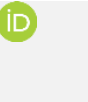

\begin{abstract}
The teaching of grammar within the teaching of the mother tongue has been handled in various ways in the historical process. Today, grammar is seen as a field that supports basic language skills, therefore, it is necessary to teach grammar in a functional way. The text-based grammar teaching method is used to provide functionality in grammar teaching and to implicate the rules regarding the use of language. The 2018 Turkish Language and Literature Teaching Curriculum, the current language and literature curriculum implemented in Turkey, is also regulated in accordance with this understanding. This approach of the 2018 curriculum on grammar teaching is a relatively new approach in Turkish education. For this reason, the applicability of the curriculum, the opinions of teachers about the curriculum and the effect of grammar teaching practices on students' academic achievement and attitudes towards the course is a situation that should be examined. When the application of the curriculum is examined, it is seen that the teachers have negative views against the grammar teaching approach of the curriculum and have problems in implementing it. In addition, the curriculum gives different results in terms of students according to the academic level of the school in which they are educated, and the academic success and attitudes of the students change accordingly. As a result, various arrangements are needed for effective teaching of text-based grammar teaching in our schools.
\end{abstract}

Keywords: Turkish language and literature, Text-based grammar teaching, Academic success, Attitude, Teacher opinions, School level.

Citation | Ayşegül Kayar; Fatih Veyis (2020). An Analysis of Grammar Teaching in Secondary School in Terms of Success, Attitude and Teachers 'Views. Asian Journal of Education and Training, 6(2): 149-160

History:

Received: 9 December 2019

Revised: 17 January 2020

Accepted: 20 February 2020

Published: 23 March 2020

Licensed: This work is licensed under a Creative Commons

Attribution 3.0 License (cc)

Publisher: Asian Online Journal Publishing Group
Acknowledgement: Both authors contributed to the conception and design of the study.

Funding: This study received no specific financial support.

Competing Interests: The authors declare that they have no conflict of interests.

Transparency: The authors confirm that the manuscript is an honest, accurate, and transparent account of the study was reported; that no vital features of the study have been omitted; and that any discrepancies from the features of the study have been omitted;
study as planned have been explained.

Ethical: This study follows all ethical practices during writing.

\section{Contents}

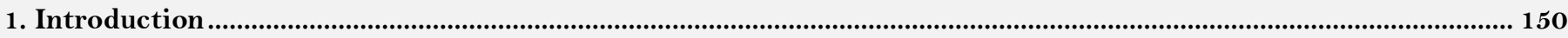

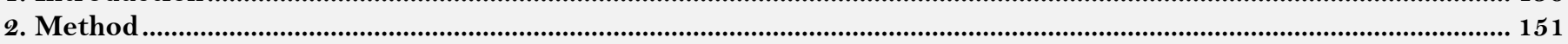

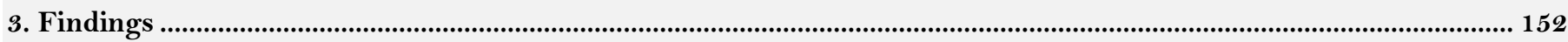

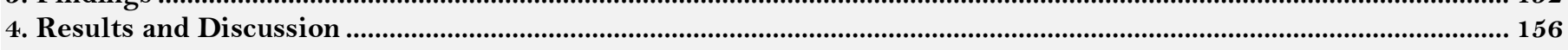

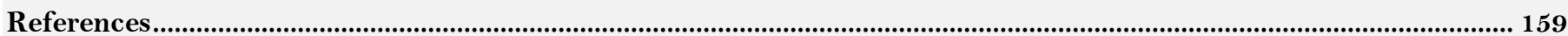




\section{Contribution of this paper to the literature}

This research focuses on the teachers' ability to fulfill the expectations of the curriculum about grammar teaching and their views on the grammar teaching approach.

\section{Introduction}

Although grammar teaching has been seen as a major skill area until recently, recent research suggests that grammar is not a separate skill area but a discipline that supports basic language skills such as reading, writing, listening and speaking. According to this understanding, teaching processes can be supported by writing, punctuation and grammar studies while teaching and understanding activities in mother tongue teaching are emphasized (Sever, 2000). The examinations made at the level of sound, word and sentence during grammar studies also help us to think more accurately and flawlessly and thus to speak and write correctly (Kavcar, Oğuzkan, \& Sever, 2005). On the other hand, messages that are not encoded in accordance with grammar rules in the understanding processes are more difficult to perceive and thus interrupt listening and reading processes (Aslan, 2017). Simşek (1983) states that a person who has a good grasp of the functioning of his mother tongue can easily understand what he read and completely explain what he hears and thinks.

With the understanding of "new grammar" developed after the 1970s, it is observed that the individuals will learn the functions and rules of their mother tongue and explore the logic and functioning of the language and use them in literacy processes (Güneş, 2017). Cemiloğlu (2003) states that the Turkish language and literature course should support the understanding and expression skills with a functional approach rather than focusing on the rules, and studies should be made to introduce language-related rules in this process. With these developments, the necessity of conducting grammar teaching with functional processes, seeing the examples as a whole, and determining the role within this integrity emerged. This integrity is the texts involved in grammar instruction. Accordingly, grammar instruction should be applied through texts and without giving the rule directly to the student, and it should be ensured that grammatical elements perceive the rule by sensing the functions they perform in the text (Göçer, 2008). Aslan (2017) states that in accordance with these views, grammar should be taught functionally, not scholastic and based on memorization. To do this, the student should think on the language through the examples and clues in the text, and based on these, he/she should sense the rule and perceive it him/herself.

Such new approaches in grammar instruction have also appeared in curriculums. The 2018 Turkish Language and Literature Curriculum, which is the current curriculum put into practice, is based on teaching grammar subjects through literary texts in accordance with this understanding. In the specific objectives of the curriculum, the expression "introducing the subtleties of Turkish to students through literary texts" is included in this regard (MEB, 2018).

Under the title of issues to be considered in the implementation of the curriculum, literature education has been handled as a ground in which students will discover the subtleties of the language and develop their language awareness and skills in addition to gaining information about literature. The following expressions were used for grammar studies in Turkish language and literature courses: "Grammar studies will be carried out on the relevant texts in the units based on the information acquired by the students in previous educational levels. Subjects will not be covered. Short explanations can be made for the purpose of reminding about the subjects they have learned in previous education levels." (MEB, 2018). These expressions, which can be regarded as a method explanation for teaching grammar, propose to put the texts in the center in grammar teaching. At this point, the text, which is an example of each literary genre, is also seen as a course material on which grammar studies can be performed. On the other hand, the assumption of the curriculum that the student can find examples of grammar subjects with the information s/he obtained in primary education is remarkable. This assumption, which is one of the points that this research focuses on, ignores the possible shortcomings of the student's prior knowledge and limits them to short reminders.

In the section where the qualities of the texts to be included in the textbook are specified in the curriculum, there is nothing mentioned about the features that should be found in terms of grammar while specifying the content, genre and literary aspects of the texts to be included. This can be interpreted as paying attention to the genre and literary characteristics of the selected texts and putting grammar into the second plan, and teaching grammar is not specifically addressed. The same case applies to the number and duration of acquisitions. Accordingly, separate acquisitions have been determined for poetry, narrative texts, plays and instructive text types within the reading acquisitions, the grammar studies in this field are roughly expressed as "He does grammar studies based on the text" only if being repeated in the same way in each title. Among the writing acquisitions, the acquisitions that can be associated with the grammar field are as follows:

- Uses terms, concepts, idioms, proverbs and dialects according to the type of text.

- Writes by paying attention to the characteristics (clarity, fluency, clearness and simplicity) that should be in a good expression.

- Uses different sentence structures and types; simple, compound, ordered, bound, subtracted, transpose, regular sentence, noun and verb sentences.

- Reviews the text s/he's written in terms of grammar, spelling, punctuation, clarity, clearness, fluency, simplicity and vocabulary preferences (MEB, 2018).

Among the acquisitions of speaking skill, those that can be associated with grammar are determining the elements of communication such as sender, receiver, message, channel code, context, feedback; speaking by paying attention to articulation, highlighting, intonation and pausing; and avoiding unnecessary sounds and words when speaking (MEB, 2018).

Even though the studies on teaching grammar through texts take many years, the fact that it is included in the curriculum is a new situation for Turkish language and literature (TLL) education. Therefore, in the light of recent changes in the curriculum, the question about how mother tongue teaching affects students' achievements and attitudes towards the course in TLL is awakened. For this reason, the question "How does grammar teaching at 
the secondary education level affect the academic achievement of students and their attitude towards the course" constitutes the main problem of our research. The approach of the 2018 Turkish Language and Literature Curriculum on grammar teaching has a new view for teachers. Thus, it is one of the main problems that our research focuses on the teachers' ability to fulfill the expectations of the curriculum about grammar teaching and their views on the grammar teaching approach.

In order to better explain the main problem addressed by the research, the sub-problems identified by considering various variables can be listed as follows:

1. Do the students' academic achievement pre-test scores and post-test scores differ significantly?

2. Do students' Turkish language and literature course attitude pre-test scores and post-test scores differ significantly?

3. Do the academic achievement scores of the students in the field of grammar differ significantly according to the school level?

4. Is there a significant relationship between students' academic achievements and their attitudes towards the Turkish language and literature course?

5. What are the opinions of the Turkish language and literature teachers regarding the grammar teaching processes included in the 2018 Turkish language and literature curriculum?

6. What are the opinions of the Turkish language and literature teachers regarding the use of grammar teaching processes in the classroom in the 2018 Turkish language and literature curriculum?

\section{Method}

The research is planned as a case study. Yin (2002) defines case studies as a research approach that focuses more on current events in real life, in which the researcher has little control over cases, and also when seeking answers to how and why questions. Yıldırım and Simşek (2011) state that, in addition to this view, it is a research method that allows examining a case or phenomenon in depth.

Our study was designed in accordance with the embedded case study research design according to the number of cases handled (Yin., 2009). According to this, grammar teaching in the $9^{\text {th }}$ grades of secondary education has been determined as the basic case of the research, and this is divided into two different phases as in terms of student and in terms of the teacher. While examining the academic achievement and attitudes of students during the examination of grammar in terms of students, the opinions of teachers about the current curriculum and their ability to apply the program in their own courses were examined.

\subsection{Research Group}

The study was carried out with 75 students and 12 Turkish language and literature teachers. Stratified purposeful sampling method was used to determine the study group (Büyüköztürk., Kılıç, Akgün, Karadeniz, \& Demirel, 2017). Three different levels of schools were determined according to the student placement points in the city center of Erzurum, and the classes were randomly selected. A total of 100 students were reached in order to eliminate data loss that may occur during applications or during extreme value analysis. Among these students, a total of 75 students, including 25 students from each school, providing parametric values were included in the process. The teachers are all the Turkish language and literature teachers working in schools from which the students were selected.

The reason for the study to be carried out particularly with the $9^{\text {th }}$-grade students is that it is stated in the 2018 TLL Curriculum that grammar teaching is carried out based on the knowledge of students in primary education and without covering the subject. Therefore, the $9^{\text {th }}$-grade level, which is the first stage in the transition from primary to secondary education, was preferred.

\subsection{Data Collection Tools}

The Turkish literature course attitude scale developed by Veyis (2015) was used to measure students' attitudes during the research process. In order to measure the academic success of students, the $9^{\text {th }}$ Grade Grammar Achievement Test, consisting of 20 questions with five options and multiple choices covering the $9^{\text {th-grade }}$ first term's grammar subjects, was developed. The test is at medium difficulty according to the difficulty levels of the questions. During the development of the test, opinions of 3 field experts and 2 Turkish language and literature teachers were taken to ensure validity and reliability. A semi-structured interview protocol consisting of 7 questions was developed in order to determine the opinions of the teachers about the curriculum and their application of the curriculum in their classes.

In the research process, three different schools, whose successes were determined according to secondary education placement scores, were selected, and the necessary official permissions were granted for the implementation in these schools. Schools are coded as A (advanced level), B (intermediate level) and C (low level), respectively, according to their academic success levels. Teachers are also coded as A, B and C according to the type of school they work in. $9^{\text {th }}$ Grade Grammar Achievement Test and Turkish Literature Course Attitude Scale were applied to the students as a pretest, and post-test applications were carried out in the same classes at an interval of approximately 11 weeks. In this process, a total of 100 students were reached, the scales and tests were systematically filled in, and lost data were analyzed and extreme value analysis was performed. As a result, a total of 75 students, 25 students from each school, were selected, and statistical analyses were made using the SPSS software. Teacher interviews were made face to face within the specified 11-week period.

\subsection{Data Analysis}

The data obtained in the data analysis process were first transferred to the SPSS environment, then extreme value analyses were performed, and it was seen that there was no extreme value in the data set. When the median, arithmetic mean, z scores, skewness and kurtosis values were examined, it was seen that the data had a normal distribution and was suitable for parametric analysis. Mertens. (2019) states that taking Skewness and Kurtosis 
values between -2 and +2 provide the normal distribution condition. In this direction, it is seen that Skewness and Kurtosis values obtained in the descriptive analysis related to the data set meet the normal distribution condition.

In order to answer the sub-problems determined in the scope of the research, t-Test, Single Factor Variance Analysis (ANOVA), Pearson Product-Moment Correlation analyses were performed for Dependent Samples. Descriptive analysis was made in the analysis of the data obtained from teacher interviews. Teachers' responses are gathered under two themes to suit sub-problems: 1. Teachers' thoughts on the grammar teaching approach of the 2018 Turkish language and literature curriculum, 2. Teachers' ability to apply the curriculum in their lessons. While analyzing the answers given to the questions, each question was evaluated separately, and quotations from the statements of the teachers were included.

\section{Findings}

\subsection{Findings Related to Students}

In this part of the study, the statistical analysis and the findings obtained from these analyses are given to determine the effect of grammar teaching in secondary schools on students' academic achievement and attitudes towards Turkish language and literature. Sub-Problem 1. Do the students' academic achievement pre-test scores and post-test scores differ significantly?

The dependent sample t-test was conducted to determine whether the academic achievements of $9^{\text {th }}$-grade students studying in different types of schools on grammar differ significantly according to their pretest and posttest scores, and the results are indicated in Table 1 . In order to perform a dependent sample t-test, it is required that the scores must be at least equal-interval scale and scores of the two associated measurement sets should be normally distributed (Büyüköztürk, 2006). In this direction, the necessary conditions are provided for analysis.

Table-1. Dependent sample T-Test results regarding academic achievement pretest and posttest scores.

\begin{tabular}{c|c|c|c|c|c|c}
\hline Variable & & $\mathbf{n}$ & $\mathbf{X}$ & $\mathbf{S s}$ & $\mathbf{t}$ & $\mathbf{p}$ \\
\hline Academic & Pretest & 75 & 45.26 & 16.64 & & \\
\cline { 2 - 7 } achievement & Posttest & 75 & 49.40 & 20.43 & -3.10 & .003 \\
\hline
\end{tabular}

When Table 1 was examined, it was seen that students' academic achievement pre-test and post-test scores related to grammar differed significantly $\left(\mathrm{t}_{74}=-3.10, \mathrm{p}<.01\right)$. Accordingly, it can be said that grammar teaching practices carried out at the $9^{\text {th }}$ grade of secondary education have a significant effect on academic achievement across the research group.

Sub-Problem 2. Do students' Turkish language and literature course attitude pre-test scores and post-test scores differ significantly?

In order to determine whether the attitudes of $9^{\text {th }}$-grade students studying at schools with different academic achievements differ significantly according to the pre-test and post-test scores, a separate dependent sample t-test was conducted for each school level. The results of the test carried out are given below on a separate table for each school level.

Table-2. Dependent sample t-test results regarding Turkish language and literature course attitude pretest and posttest scores at A level school.

\begin{tabular}{l|c|c|c|c|c|c}
\hline Variable & & $\mathbf{n}$ & $\mathbf{X}$ & $\mathbf{S s}$ & $\mathbf{t}$ & $\mathbf{p}$ \\
\hline \multirow{2}{*}{ Interest } & Pretest & 25 & 27.67 & 7.60 & \multirow{2}{*}{2.72} & \multirow{2}{*}{.012} \\
\cline { 2 - 6 } & Posttest & 25 & 23.36 & 10.66 & & \\
\hline \multirow{2}{*}{ Amportance } & Pretest & 25 & 30.04 & 6.39 & 2.65 & \multirow{2}{*}{.014} \\
\cline { 2 - 6 } & Posttest & 25 & 26.92 & 8.80 & & \\
\hline \multirow{2}{*}{ Knowledge } & Pretest & 25 & 14.52 & 4.98 & \multirow{2}{*}{4.27} & \multirow{2}{*}{.000} \\
\cline { 2 - 6 } & Posttest & 25 & 11.08 & 5.51 & & \\
\hline \multirow{2}{*}{ Attitude Total Score } & Pretest & 25 & 14.83 & 2.62 & \multirow{2}{*}{4.09} & \multirow{2}{*}{.000} \\
\cline { 2 - 6 } & Posttest & 25 & 12.72 & 3.95 & & \\
\hline
\end{tabular}

When Table 2 is examined, it is seen that there is a differentiation in the interest sub-dimension $\left(t_{24}=2.72\right.$, $\mathrm{p}<.05)$, importance sub-dimension $\left(\mathrm{t}_{24}=2.65, \mathrm{p}<.05\right)$, avoidance sub-dimension $\left(\mathrm{t}_{24}=4.27, \mathrm{p}<.01\right)$ and knowledge sub-dimension $\left(\mathrm{t}_{24}=4.09, \mathrm{p}<.01\right)$ of the pre-test and post-test scores of students studying at A level school towards Turkish language and literature course.

Table-3. Dependent sample t-test results regarding attitude pre-test and post-test scores against Turkish language and literature course at B level school.

\begin{tabular}{l|c|c|c|c|c|c}
\hline Variable & & $\mathbf{n}$ & $\mathbf{X}$ & $\mathbf{S s}$ & $\mathbf{t}$ & $\mathbf{p}$ \\
\hline \multirow{2}{*}{ Interest } & Pretest & 25 & 32.32 & 9.14 & 1.72 & \multirow{2}{*}{.097} \\
\cline { 2 - 6 } & Posttest & 25 & 28.96 & 11.80 & & \\
\hline \multirow{2}{*}{ Amportance } & Pretest & 25 & 30.52 & 6.48 & 2.24 & \multirow{2}{*}{.034} \\
\cline { 2 - 6 } & Posttest & 25 & 26.24 & 9.85 & & \\
\hline \multirow{2}{*}{ Knowance } & Pretest & 25 & 15.24 & 5.08 & 2.25 & \multirow{2}{*}{.034} \\
\cline { 2 - 6 } & Posttest & 25 & 12.48 & 5.19 & & \\
\hline Attitude Total Score & Pretest & 25 & 15.80 & 2.76 & \multirow{2}{*}{2.46} & \multirow{2}{*}{.021} \\
\cline { 2 - 6 } & Posttest & 25 & 13.84 & 4.48 & & \\
\hline
\end{tabular}


According to the findings obtained, it is seen that the attitudes of A school students towards Turkish language and literature course between the pre-test and post-test applications over a period of time were negative in terms of interest, importance and knowledge, and the avoidance of the course decreased at the end of the process.

When Table 3 is examined, it is seen that there is a significant differentiation in the importance sub-dimension $\left(\mathrm{t}_{24}=2.24, \mathrm{p}<.05\right)$, avoidance sub-dimension $\left(\left(\mathrm{t}_{24}=2.25, \mathrm{p}<.01\right)\right.$ and knowledge sub-dimension $\left(\mathrm{t}_{24}=2.46, \mathrm{p}<.01\right)$ of the pre-test and post-test scores of students studying at B level school towards Turkish language and literature course. According to the findings, it can be said that in the time interval between the pre-test and post-test applications of the B school students, the sub-dimensions of knowledge and importance has improved positively in the attitudes of B school students towards Turkish language and literature, and their avoidance of the lessons has decreased. On the other hand, it is seen that there is no significant difference in the sub-dimension of interest $\left(t_{24}=\right.$ $1.72, \mathrm{p}>.05)$ between the pre-test and post-test scores of the students. This finding can be interpreted as the fact that the grammar teaching practices carried out in B school did not make a significant difference in the students' interests towards the lesson.

Table-4. Dependent sample t-test results regarding attitude pre-test and post-test scores against Turkish language and literature course at C level school.

\begin{tabular}{l|c|c|c|c|c|c}
\hline Variable & & $\mathbf{n}$ & $\mathbf{X}$ & $\mathbf{S s}$ & $\mathbf{t}$ & $\mathbf{p}$ \\
\hline \multirow{2}{*}{ Interest } & Pretest & 25 & 36.92 & 8.21 & \multirow{2}{*}{-.45} & .656 \\
\cline { 2 - 6 } & Posttest & 25 & 37.79 & 8.71 & & \\
\hline \multirow{2}{*}{ Importance } & Pretest & 25 & 32.24 & 5.14 & -.37 & .713 \\
\cline { 2 - 6 } & Posttest & 25 & 32.72 & 5.49 & & \\
\hline \multirow{2}{*}{ Knoidance } & Pretest & 25 & 16.56 & 3.54 & \multirow{2}{*}{1.27} & .215 \\
\cline { 2 - 6 } & Posttest & 25 & 15.20 & 4.94 & & \\
\hline Attitude Total Score & Pretest & 25 & 15.84 & 2.64 & \multirow{2}{*}{-.17} & \multirow{2}{*}{.865} \\
\cline { 2 - 5 } & Posttest & 25 & 15.96 & 3.45 & & \\
\hline
\end{tabular}

When Table 4 is analyzed, it is seen that there is no significant differentiation in the interest sub-dimension $\left(\mathrm{t}_{24}=-.45, \mathrm{p}<.05\right)$, importance sub-dimension $\left(\mathrm{t}_{24}=-.37, \mathrm{p}<.01\right)$, avoidance sub-dimension $\left(\mathrm{t}_{24}=1.27, \mathrm{p}<.01\right)$ and information sub-dimension $\left(\mathrm{t}_{24}=-.17, \mathrm{p}>.05\right)$ of the pre-test and post-test scores of students studying at $\mathrm{C}$ level school towards Turkish language and literature course. According to the findings obtained, it can be concluded that the grammar teaching practices carried out at $\mathrm{C}$ school did not make a significant change in students' attitudes towards the Turkish language and literature course.

Sub-Problem 3. Do the academic achievement scores of the students in the field of grammar differ significantly according to school level?

In order to determine whether the difference between the grammar achievement scores of $9^{\text {th }}$-grade students studying in schools with different academic success levels differed according to the level of achievement, the academic achievement pretest scores of each student were first removed from the academic achievement post-test scores and as a result, gain scores were obtained. Then, Single Factor Variance Analysis (ANOVA) was performed to determine whether these scores differ significantly according to school levels. It was seen that variance homogeneity, which is the prerequisite of ANOVA, was provided $(\mathrm{F}(2,72)=.352, \mathrm{p}>.05)$.

Table-5. ANOVA results regarding school level and academic success variables.

\begin{tabular}{c|c|c|c|c|c|c|c}
\multicolumn{7}{c}{ Table-5. ANOVA results regarding school level and academic success variables. } \\
\cline { 1 - 4 } School Level & $\mathbf{n}$ & $\mathbf{X}$ & Ss & Sd & $\mathbf{F}$ & $\mathbf{p}$ & Difference \\
\hline School A & 25 & 9.00 & 10.00 & & & & A-C \\
\hline School B & 25 & 5.40 & 10.98 & $2 / 72$ & 6.824 & .002 & B-C \\
\hline School C & 25 & -2.00 & 11.18 & & & & \\
\hline
\end{tabular}

When Table 5 is analyzed, as a result of ANOVA conducted to determine whether the gain scores of $9^{\text {th }}$-grade students studying at schools with different academic success levels differ, it was found that the academic achievement gain scores of students differed significantly according to the level of the school $\left(\mathrm{F}_{(2,72)}=6.824, \mathrm{p}<.05\right)$. LSD, which is one of the Multiple Comparison Tests, was used to determine among which means the source of this difference was. According to the analysis, the academic achievement points of the $\mathrm{C}$ school students differed significantly from A and B school students. The average of academic achievement gain points of $\mathrm{C}$ school students is $\mathrm{X}=-2.00$, the average of academic achievement gain points of $\mathrm{A}$ students is $\mathrm{X}=9.00$, and the average of academic achievement gain points of $\mathrm{B}$ students is $\mathrm{X}=5.4 \mathrm{O}$. Based on this finding, it can be said that the academic achievement level of the school is a variable that significantly affects the grammar academic achievement gain score.

Sub-Problem 4. Is there a significant relationship between students' academic achievements and their attitudes towards the Turkish language and literature course?

Pearson Product-Moment Correlation analysis was carried out to determine whether there is a significant relationship between the academic achievements of $9^{\text {th }}$-grade students studying in schools with different academic success levels and their attitude towards the Turkish language and literature course. The obtained findings are indicated in Table 6.

Table-6. The relationship between academic success and attitude towards Turkish language and literature course.

\begin{tabular}{c|c|c|c|c|c}
\hline Variable & Interest & Importance & Avoidance & Knowledge & Attitude Total Score \\
\hline Academic achievement & $-.426^{* *}$ & -.204 & -.201 & $-.283^{*}$ & $-.338^{* *}$ \\
\hline Note: * $\mathrm{p}<.05, * * \mathrm{p}<.01$.
\end{tabular}

When Table 6 is examined, it is seen that there is a negative but significant relationship between the interest and knowledge sub-dimensions of attitude towards Turkish language and literature course and academic 
achievement in grammar and total scores. Based on this finding, it can be concluded that if the academic success in grammar increases, the interest in the attitude towards the Turkish language and literature lesson in students and the value given to the knowledge in this field decreases. As a result of the analysis, no statistically significant relationship was found between academic achievement in grammar and the importance and avoidance subdimension of attitude towards the Turkish language and literature course.

\subsection{Findings Related to Teachers}

Sub-Problem 5. How are the opinions of the Turkish language and literature teachers formed regarding the grammar teaching processes included in the 2018 Turkish Language and Literature Curriculum?

Question 1: What do you think about the integration of Turkish literature and grammar subjects? What are the advantages and disadvantages, if any, for you?

\begin{tabular}{c|c|c|c}
\multicolumn{2}{c}{ Table-7. The views of Turkish language and literature teachers on the integration of Turkish literature and grammar subjects. } \\
\hline $\begin{array}{c}\text { School } \\
\text { Level }\end{array}$ & $\begin{array}{c}\text { I Find It Advantageous / } \\
\text { Positive }\end{array}$ & I Find Disadvantageous / Negative & $\begin{array}{c}\text { It has Advantages and } \\
\text { Disadvantages }\end{array}$ \\
\hline School A & $\mathrm{A} 1, \mathrm{~A} 4$ & $\mathrm{~A} 3$ & $\mathrm{~A} 2$ \\
\hline School B & - & $\mathrm{B} 1, \mathrm{~B} 2$ & - \\
\hline School C & - & $\mathrm{C} 2, \mathrm{C} 3, \mathrm{C} 6$ & $\mathrm{C} 1, \mathrm{C} 4, \mathrm{C} 5$ \\
\hline Total & 2 & 6 & 4 \\
\hline
\end{tabular}

Based on their answers to the research question, $50 \%$ of Turkish language and literature teachers think that integration Turkish literature and grammar subjects negatively affect the course. On the other hand, 33.33\% stated that this integration has negative outcomes as well as positive outcomes. Only $16.66 \%$ of the teachers expressed a positive opinion about the integration of these lessons.

According to the statements of the teachers who stated a positive opinion about the integration of Turkish literature and grammar subjects, the based instruction of grammar subjects and exercises on texts is more useful than the previous ones. The organization of the curriculum in this way allows these two interrelated courses to be taught in a more holistic and tidy way. Besides, it is also stated by teachers that a teacher can see the class in all aspects with this application and that the 2018 Turkish Language and Literature Curriculum is a better one in terms of training time and subjects compared to the previous ones.

A4: I consider this integration correct and useful. I believe that the instruction of grammar subjects without text will not benefit the student. When the subjects are integrated, we can practice the literary texts in the textbooks about the subject of grammar we want.

The opinions of teachers, which can be considered as negative related to the integration of Turkish literature and grammar subjects, are basically that this integration only remains in theory, there are problems in practice and two lessons are carried out separately though. It was stated that this problem in practice was primarily due to the confusion of students, the inability to think of two lessons together, and the fact that it was not appropriate to conduct grammar studies on literary texts, especially with students with low levels. Therefore, teachers also do separate grammar lessons as well as literature lessons. In addition, it was also stated that this integration caused one of the two lessons to be neglected, the balance could not be established between the two lessons, and the subject in which the teacher felt strong was focused on the subject.

A3: I do not find it positive to integrate grammar and literature lessons. Integrating these lessons causes one of both courses to be neglected. The teacher, who is better at the grammar field, focuses on grammar, and the teacher who is better at literature focuses on literature.

B1: I don't think it's advantageous. Because when these lessons are integrated, confusion and bemusement occurred in the students. When telling the subject of story in the literature lesson, suddenly starting to talk about adjective causes makes children to be confused. Although integrated, a duality emerges when applying.

Question 2: What do you think about the absence of phonetics and morphology subjects in the 2018 Turkish Language and Literature Curriculum?

All of the teachers (12) think that within the curriculum, phonology and morphology should be included in grammar subjects. The majority of teachers are of the opinion that the subjects of phonology and morphology are one of the basic subjects of the Turkish language and that these subjects should be taught in order for the student to understand the Turkish language better.

C1: Phonology and morphology subjects are the basic subjects of Turkish. These had to be included.

In addition, three teachers stated that the topics of phonology and morphology were necessary for the understanding of the spelling rules for the student, while a teacher stated that the same requirement also applies to the subjects of rhyme-redif and elements of the sentence.

A2: I find it negative. I also emphasize this in lessons. They need to know the morphology about rhyme and

redif. I remind them of the consonant assimilation when the spelling rules are taught. Morphology is required in the elements of the sentence.

While two teachers stated that the subjects of phonology and morphology were one of the issues that students had difficulty in learning, one of them stated that they could not learn these subjects in primary education. One teacher emphasized that the topics of phonology and morphology should be taught as they are asked in the central exams that students enter.

C3: This also caught my attention. Especially the correct use and application of spelling rules necessitate these subjects. This is important. So it should have included the subjects of phonetics. When it comes to morphology, while teaching word types (noun, adjective, etc.), we can also teach these types in terms of structure. If these subjects will be faced by the student as a question in TYT and ATT (central examinations), it is an inconsistency that they are not included in the curriculum.

Question 5: In your opinion, do the texts given in the textbooks for teaching grammar topics provide sufficient examples to explain the determined grammar topics? Why? 
Table-8. The views Turkish language and literature teachers about the texts in the textbooks.

\begin{tabular}{c|c|c}
\hline $\begin{array}{c}\text { School } \\
\text { Level }\end{array}$ & $\begin{array}{c}\text { The text in the textbooks provides sufficient } \\
\text { examples for grammar teaching. }\end{array}$ & $\begin{array}{c}\text { The texts in the textbooks do not provide } \\
\text { sufficient examples for grammar teaching. }\end{array}$ \\
\hline School A & $\mathrm{A} 1$ & $\mathrm{~A} 2, \mathrm{~A} 3, \mathrm{~A} 4$ \\
\hline School B & - & $\mathrm{B} 1, \mathrm{~B} 2$ \\
\hline School C & $\mathrm{C} 2, \mathrm{C} 3$ & $\mathrm{C} 1, \mathrm{C} 4, \mathrm{C} 5, \mathrm{C} 6$ \\
\hline Total & 3 & 9 \\
\hline
\end{tabular}

While $25 \%$ of Turkish language and literature teachers think that the texts in the textbooks provide sufficient examples for grammar teaching, $75 \%$ think that the texts in the textbooks are insufficient for grammar subjects. Three of the teachers interviewed think that basically different text is given for each grammar subject and this provides sufficient examples.

A1: I think it is sufficient to explain grammar topics as different texts are given for each subject in the textbooks.

Seven of the teachers who expressed negative opinions stated that they could not find all the examples of the grammar subject in the texts given in the textbooks, therefore the texts were not sufficient for grammar teaching.

A2: It certainly does not, because when the subject of names is being taught, the text in the book may not include an example of a name.

Two of the teachers think that the grammar activities given in the textbooks are insufficient. They stated that this does not enable students to practice grammar subjects at a sufficient level.

B1: It does not provide. There are only one or two activities. Although the children say they understand the subject, they cannot solve the questions in the tests. This shows that the activities are not enough. Because books are mostly literature oriented.

Question 7: What can be done for more effective grammar teaching? What are your suggestions on this subject?

In line with the answers given by the teachers to the research question, the suggestions they have made regarding the teaching of a more effective grammar than the existing grammar instruction can be listed as follows:

- $\quad$ The time spared on teaching grammar should be increased. $(A 1, B 2)$

- Grammar subjects should be explained in detail. (A3, A4)

- More practice should be done on the texts. $(A 3, B 2, C 5)$

- $\quad$ The texts given in the textbooks should be selected from the texts including more examples on the subject, the number of texts in the textbook should be increased, and a rich text archive should be created for teaching grammar subjects. (A2, $A 4, C 3)$

- $\quad$ The number of writing activities should be increased, and the permanence of the subjects learned should be ensured. (A2, C4, C6)

- Literature and grammar subjects should be given as separate lessons. (C3, C6)

- Grammar subjects should be taught in real life, not with anxiety about the exam. (B1, C5)

- Resources and material diversity should be increased. (C1, C5)

- Grammar education should be provided to students with a solid foundation at the primary level, and the student who comes to the high school level should be able to practice more easily. (C2)

- The number of measurement and evaluation questions at the end of the units should be increased.(C3)

- $\quad$ The level in textbooks is a bit high, so the subjects should be made a little easier. (C3)

- Types of instruction and ways of developing thought should be added to the curriculum. (C3)

- Attention should be paid to the subject order. (A2)

- Phonology and morphology should be included in the curriculum. (A1)

- More attention should be given to reading books. (C4)

- New teaching methods should be developed by experts. (C4)

- Not only Turkish language and literature teachers, but teachers in all branches should also be careful about grammar. (A1)

When the answers given by teachers to the research question are evaluated in general, it is seen that they have the idea that some improvements should be made in grammar teaching. Some of the teachers suggest that a separate lesson should be included apart from the literature course to improve grammar teaching in our schools. Other teachers, on the other hand, think that it is a good practice to study grammar subjects with a literature lesson, but the texts in the textbook should be chosen among more productive texts for grammar applications. Teachers believe that application-oriented methods and techniques should be used in teaching grammar. It is also stated that teachers need richer resources and expert help.

Sub-Problem 6. What are the views of the Turkish language and literature teachers regarding the use of grammar teaching processes of the 2018 Turkish Language and Literature Curriculum in their classrooms?

Question 3: Do you lecture the subject of grammar in your lessons? Why?

Table-9. Turkish language and literature teachers' preference for instruction in grammar lessons.

\begin{tabular}{c|c|c|c}
\hline School Level & I Lecture & I don't Lecture & Sometimes I lecture and sometimes I don't \\
\hline School A & $\mathrm{A} 1, \mathrm{~A} 2, \mathrm{~A} 3$ & - & $\mathrm{A} 4$ \\
\hline School B & $\mathrm{B} 1, \mathrm{~B} 2$ & - & - \\
\hline School C & $\mathrm{C} 1, \mathrm{C} 2, \mathrm{C} 3, \mathrm{C} 4, \mathrm{C} 5, \mathrm{C} 6$ & - & - \\
\hline Total & 11 & 0 & 1 \\
\hline
\end{tabular}

When the table was examined, it was found that no teacher stated that they do not lecture in the teaching of grammar subjects. It is seen that the majority of teachers prefer lecturing during the processing of grammar subjects in Turkish language and literature. This majority, which has a rate of $91.66 \%$, stated that students had difficulty in understanding these subjects and that the subjects should be understood better by the students as the 
reason for their preference for lecturing in the teaching of grammar subjects. In addition, the teachers working at the $\mathrm{C}$ level school stated that the students could not learn these subjects adequately in primary education, their level of readiness was quite low, and that is why they lecture on these subjects. According to the opinions of the teachers who stated that they have lectured, the student who did not have a theoretical command of grammar had problems in determining the examples of the subject on literary texts.

A1: I give lectures because the student has difficulty in understanding and practicing the subject. But I devote more time to implementation.

B2: Yes. The student cannot understand very well without teaching the subject. So do not lecture, the technique of foreshadowing is not very suitable.

C1: I do because the success of the school is low, so the students are very lacking in terms of subjects, so I give a lecture first. I lecture the subject from scratch.

When the research questions were examined, the only Turkish language and literature teacher who stated that in some cases he lectured the subject and in some cases directly applied, stated that he acted according to the readiness of the students. The only teacher who can determine the course teaching process in accordance with the 2018 Turkish Language and Literature Curriculum in the processing of grammar subjects works at A school.

A4: I act according to my student's readiness. If they do not have any information on the subject, I give quick

facts and study grammar in the text.

Question 4: What grammar subjects do you pay attention to when evaluating the writing assignments you give to your students at the end of the unit?

Table-10. The matters Turkish language and literature teachers consider when evaluating students' writing homework.

\begin{tabular}{c|c|c|c|c}
\hline School Level & Punctuation & Spelling & Ambiguity & Content \\
\hline School A & $\mathrm{A} 1, \mathrm{~A} 2, \mathrm{~A} 3, \mathrm{~A} 4$ & $\mathrm{~A} 1, \mathrm{~A} 2, \mathrm{~A} 3, \mathrm{~A} 4$ & $\mathrm{~A} 1, \mathrm{~A} 2$ & - \\
\hline School B & $\mathrm{B} 1, \mathrm{~B} 2$ & $\mathrm{~B} 1, \mathrm{~B} 2$ & - & - \\
\hline School C & $\mathrm{C} 1, \mathrm{C} 2, \mathrm{C} 3, \mathrm{C} 4, \mathrm{C} 6$ & $\mathrm{C} 1, \mathrm{C} 2, \mathrm{C} 3, \mathrm{C} 4, \mathrm{C} 5, \mathrm{C} 6$ & - & $\mathrm{C} 5, \mathrm{C} 6$ \\
\hline Total & 11 & 12 & 2 & 2 \\
\hline
\end{tabular}

According to the findings obtained from the answers given by the teachers to the research question, it is seen that almost all of them pay attention to the spelling and punctuation issues in the writing tasks of the students. The approach of the curriculum in this regard is that the topics of writing and punctuation are not given as a single class and a single unit, but are distributed throughout the classes and units. Accordingly, the teachers' approach in this subject is compatible with the curriculum. On the other hand, two teachers stated that they were paying attention to whether there was any ambiguity while evaluating the writing assignments they gave to students as well as writing and punctuation, and it was found that both teachers were careful about the content of the assignments.

Question 6: Do you use any material other than textbooks and texts in them when you teach grammar subjects? If yes, what are they?

Table-1 1. Turkish language and literature teachers' use of materials other than textbooks.

\begin{tabular}{c|c|c|c}
\hline School Level & $\begin{array}{c}\text { I don't use any material } \\
\text { other than these }\end{array}$ & $\begin{array}{c}\text { I bring other texts to } \\
\text { the lesson }\end{array}$ & $\begin{array}{c}\text { I use different materials } \\
\text { besides texts }\end{array}$ \\
\hline School A & - & $\mathrm{A} 1, \mathrm{~A} 2, \mathrm{~A} 4$ & $\mathrm{~A} 1, \mathrm{~A} 3, \mathrm{~A} 4$ \\
\hline School B & - & $\mathrm{B} 1, \mathrm{~B} 2$ & $\mathrm{~B} 1, \mathrm{~B} 2$ \\
\hline School C & $\mathrm{C} 2$ & - & $\mathrm{C} 1, \mathrm{C} 3, \mathrm{C} 4, \mathrm{C} 5, \mathrm{C} 6$ \\
\hline Total & 1 & 5 & 10 \\
\hline
\end{tabular}

According to the answers given by the teachers to the research question, it was determined that the majority of teachers chose different materials other than textbooks. Five of the teachers interviewed stated that they used other texts during the teaching of grammar subjects besides the texts in the textbook. It was observed that the teachers who supported the teaching process with different texts other than the texts in the textbook are the teachers working at $\mathrm{A}$ and $\mathrm{B}$ schools, and the teachers working at the $\mathrm{C}$ school chose sources with lectures related to grammar except for the texts in the textbook in their lessons.

A1: I am trying to use leaf tests and texts that I have determined.

A2: I am bringing different texts into the classroom. Sometimes I give homework from texts that students can

find while giving a performance project.

On the other hand, it was seen that ten teachers chose different materials other than texts. Based on the expressions of the teachers who chose the materials other than the texts during the teaching process, four teachers use worksheets and leaf tests, four teachers use the smartboard and EBA (Educational Informatics Network) presentations, three teachers use the source with lectures, and two teachers use the materials they obtain from various websites.

B2: I use some sites on the internet. I use activity books. I give priority to the texts in the textbooks, but if necessary, I bring other texts on the subject.

C5: I use EBA tests and application-style tests.

One teacher stated that $\mathrm{s} /$ he did not use different texts and materials for grammar subjects, except for the texts in the textbook.

C2: I do not use any other text, but I try to increase understanding with concept maps.

\section{Results and Discussion}

4.1. Results Related to the Students

According to the findings obtained during the research process, when the study group was evaluated in general, it was seen that there was a significant difference between the pre-test and post-test scores related to 
grammar achievement levels, and there was an increase in their mean scores. In this case, it can be said that the grammar teaching carried out in the $9^{\text {th }}$ grade of secondary education has an effect on the academic success of the students in general. It can be thought that the grammar subjects learned by students in primary education are forgotten during their transition to secondary education, remembering this information with grammar activities carried out during the semester or learning these subjects better in secondary education is effective in reaching this result.

When the change in the academic achievement of the students is evaluated for each school separately, it is concluded that the academic achievement level of the school is effective on the academic achievement scores of the students in the grammar, and the difference between the academic achievement pre-test and post-test scores differ significantly according to the school level. Accordingly, the academic achievement gain points of the students studying at $\mathrm{C}$ school differed significantly from those studying at A and B school. Based on this, it was observed that teaching activities carried out in the field of grammar in A and B schools had a positive effect on students' academic achievement, whereas grammar activities carried out in this field in school $\mathrm{C}$ did not have a significant effect on students' academic achievement.

When the change of attitude scores according to schools was analyzed, it was seen that the attitudes of the students studying at the advanced level A school towards the Turkish language and literature course differ significantly in terms of their pre-test and post-test scores. It was observed that grammar teaching activities carried out in school A negatively affect students' attitudes towards the Turkish language and literature course in terms of interest, importance, avoidance and knowledge. It is concluded that there was a decrease in all subdimensions and total scores of the attitude scale in school A, and this decrease made a significant difference.

It was determined that the pretest and posttest total scores of attitude towards the Turkish language and literature course of the students studying at the B-level school with moderate success increased, and this increase was significantly different. When the sub-dimensions of the attitude scale were analyzed, it was seen that there was no significant difference in the dimension of interest, while there was a significant difference in the importance, avoidance and knowledge sub-dimensions. When evaluated in terms of total scores, it was seen that the grammar teaching activities carried out in school B positively and significantly increased students' attitudes towards the Turkish language and literature course.

On the other hand, when we look at the school C, it was seen that there was no significant difference in the students' attitudes towards Turkish language and literature lessons in the total scores of pre-test and post-test. There was no significant difference between the pretest and posttest scores in the attitude scale's interest, importance, avoidance and knowledge sub-dimensions. From this point of view, it was concluded that the grammar teaching activities carried out at school $\mathrm{C}$ did not have any effect on students' attitudes towards the Turkish language and literature course.

When evaluated in general, it was concluded that the attitudes of students towards the Turkish language and literature course were affected by the academic success level of the school in which they studied, and their attitudes differed significantly.

The results obtained regarding the relationship between students' academic achievements and their attitudes towards the Turkish language and literature course showed that there was a negative correlation between academic achievement and attitude towards the Turkish language and literature course. According to this, as academic achievement in the field of grammar increases, attitude points towards the Turkish language and literature course decrease. When analyzed in terms of its sub-dimensions, there was no correlation in importance and avoidance dimension, whereas there was a negative correlation in the sub-dimensions of interest and knowledge. When evaluated over total scores, it was seen that there was a strong and negative correlation. Based on this situation, it can be concluded that students who study at A and B schools and who have high academic achievements place importance on getting high scores from the Turkish language and literature course, but they are not interested in the course and do not value the knowledge they will learn in this course. It is seen that the students who study at school $\mathrm{C}$ and who have low academic achievement are interested in the lesson and they value the knowledge that the lesson will bring to them, but their academic achievement is low and the grammar teaching activities do not change their academic achievement.

When we look at the academic studies examining the effectiveness of the text-based grammar teaching method and contemporary teaching approaches on grammar teaching, it is seen that these are mostly research carried out at the primary level, therefore the school level factor is not included in these studies. Derman (2002) states that the use of fairy tale texts could be effective in mother tongue teaching, Ciçek (2006) states that joke texts could be effective in mother tongue and grammar teaching, and Sentürk (2008) states that tongue twisters can be effective. According to the researchers, such texts can be more effective in terms of being interesting and pleasant texts.

It is seen that experimental studies on the text-based grammar teaching method are also carried out at the primary level. It is stated that in such studies in which the researcher interferes with the teaching situations, the teaching situations arranged in accordance with the contemporary teaching approach are more effective on student achievement compared to traditional methods. In Ceçen (2007) study titled "Text-Based Grammar Teaching”, they worked on students studying at the second level of primary education. In the study carried out with the experiment group of 35 and the control group of 34, an achievement test consisting of 40 questions was applied as a pretest and a posttest. According to the data obtained, it was seen that teaching text-based grammar is more successful than the traditional method in developing students' grammar skills. In Derman. (2008) study on text selection in grammar teaching, they worked with 2 different experimental groups and 1 control group. The control group was taught by using texts in the textbook, the experimental 1 group was taught by literary texts selected by the researcher, and the experiment 2 group was taught by using the texts developed by the researcher. As a result, there was a significant difference in the academic achievement of the control and experimental groups in favor of the experimental groups, and it was proved that the choice of text in grammar teaching affects academic success. In a similar study by Ceçen. and Aytaş (2008) it was observed that the academic success of the experimental group in which the text-based grammar teaching method was applied was higher than the control group in which the traditional method was applied. It was concluded that teaching text-based grammar is more effective in improving 
grammar success. Yilmaz (2018) study is remarkable in terms of conducting grammar teaching in teaching Turkish to foreigners in a text-centered manner. After the text-based grammar activities applied to the selected group in the research process, students were able to use language structures in a communicative context as well as understanding the language structures in terms of their form, meaning and use. It was stated by the students that they can use grammatical structures in daily life outside of the lesson.

Unlike these studies, Menteş (2004) studied the effectiveness of active learning method in grammar teaching in primary education, while Yakışan (2017) studied the effectiveness of the discovery learning technique. It is concluded that the stated methods and strategies are more effective in teaching grammar.

Unlike the researches given above, our study determines the applicability of the text-based grammar teaching targeted in the curriculum by considering the levels of the schools and emphasizes the effect of grammar teaching on student success and attitude towards the course. As a result, it was observed that the school level had an important effect on the academic achievement and attitude towards the course of the students in the grammar field at secondary education level and the teaching activities did not have the same effect on the students. The research addresses an important problem in this aspect.

\subsection{Results Related to the Teachers}

When the approaches of Turkish language and literature teachers on the teaching grammar and their views on the grammar teaching processes of the 2018 Turkish Language and Literature Curriculum are evaluated, it is seen that there are general problems in implementing the curriculum. First of all, teachers mostly stated negative opinions about integrating grammar and Turkish literature classes. Based on this, it can be concluded that teachers have problems in teaching text-based grammar subjects and cannot use this method in their lessons. The teachers who stated positive views and stated that it is beneficial to use texts in the teaching of grammar subjects are the teachers who work in A school which has students with high academic achievement. On the other hand, the teachers who work at school $\mathrm{C}$ stated that it is not possible to teach grammar subjects through texts because of the low academic achievement and readiness of students. As a result, the vast majority of teachers stated that they had problems in implementing the 2018 Turkish Language and Literature Curriculum and that they carried out grammar, and Turkish literature courses separately.

Teachers also have mostly negative views about the adequacy of the texts in the textbooks in teaching grammar. Teachers think that the texts in the textbooks do not contain all the examples of the related grammar subject and that the grammar activities are insufficient in the textbooks, which negatively affects the teaching of grammar.

All of the teachers think that the subjects of phonology and morphology should definitely be included in the program, these topics are the basic topics of Turkish, and that these topics should be known in advance in order to learn topics such as spelling, rhyme and redif. Teachers also think that these subjects should be included in the curriculum as they are asked in the central exams. Based on this, teachers consider the absence of phonology and morphology in the 2018 Turkish Language and Literature Curriculum as a wrong practice.

In general, it can be said that the Turkish language and literature teachers have negative opinions about the 2018 Turkish Language and Literature Curriculum. According to the teachers, the goals of the curriculum related to grammar teaching remain in theory, and problems occur in practice. However, teachers think that integrating grammar and Turkish literature lessons has negative results, textbooks and texts in the textbooks are not suitable for teaching grammar as the curriculum requires, and phonology and morphology subjects should be included in the program.

Among the suggestions of the teachers about teaching more effective grammar, the most prominent ones are the arrangements in the curriculum, course hours and textbooks. The main ones focus on increasing the number of hours allocated to teaching grammar, increasing the number of texts selected in the textbooks, having more examples of grammar topics on these texts, and teaching a more detailed grammar and increasing the number of writing activities. Teachers' suggestions for improving grammar teaching are mostly expected to be realized by high-level institutions and experts.

Considering the situation in which Turkish language and literature teachers can apply the text-based grammar teaching method in their lessons in accordance with the 2018 Turkish Language and Literature Curriculum, it is concluded that almost all of the teachers do not use this method in their lessons. It was determined that teachers use the method of lecturing to a large extent in grammar lessons. They state students' difficulty in understanding these issues as the reason for this situation. Particularly the teachers who work in the $\mathrm{C}$ school prefer the lecturing method of choice because of the low level of students' readiness. As a result, although teachers find the method of lecturing more effective in grammar teaching and express that students understand the subject more easily with this method, they find it difficult to practice over texts and as a method above student level.

The materials chosen by teachers for teaching grammar subjects also have a similar appearance. In this regard, it was seen that teachers preferred sourcebooks with lecturing rather than the texts in the textbooks in teaching grammar. It was observed that the teachers who brought different texts to the lesson apart from the texts in the textbooks were the teachers working in A and B schools, and the teachers working in the $\mathrm{C}$ school chose sources with lecturing other than the texts.

While teachers evaluate students' writing assignments, they mostly pay attention to matters such as spelling, punctuation and ambiguity. On the other hand, it was determined that teachers did not pay attention to the use of the grammar subjects taught about the relevant unit in the students' writings and how they used these subjects within the narrative skill.

Considering the results, it is seen that Turkish language and literature teachers have problems in applying the 2018 Turkish Language and Literature Curriculum along with the text-based grammar teaching and continue to use traditional teaching methods.

It is seen that other academic studies focusing on teacher opinions in grammar teaching support the findings of this research. In their study, Sağır (2002) states that teachers do not use audiovisual tools other than textbooks when teaching grammar subjects. In addition, grammar topics in schools are taught using the direct instruction 
method, and grammar teaching cannot go beyond teaching certain definitions and rules. In the study of Ertekinoğlu (2003) as a result of the teacher interviews, it was observed that the teachers did not know the modern teaching methods and techniques sufficiently and still performed traditional rote learning. According to Erdem (2007) research, teachers mostly use textbooks and then supplementary resource books. Akgül (2010) on the other hand, determined according to their study on Turkish language teachers working in primary schools that teachers use textbooks the most and secondly supplementary resource books as teaching materials. In addition, teachers think that the number of texts suitable for grammar teaching is less in the textbooks and they make the students memorize in their lessons, so it can be said the lessons are still taught according to traditional understanding. Teachers think that the grammar program does not meet student and teacher expectations. Similarly, in the study of Carkit (2013) it has been concluded that traditional grammar teaching is still in practice due to crowded classes, technological inadequacy, low level of students 'readiness, teachers' anxiety to catch the curriculum, etc.

Among the studies on textbooks and the texts included here can be shown (Kanat, 2016) study. In the study in which $6^{\text {th }}, 7^{\text {th }}$ and $8^{\text {th }}$-grade Turkish textbooks were examined, it was determined that some of the texts in the textbooks included sufficient examples for grammar subjects to be covered, while in others there were a limited number of examples or none at all. In the research conducted by Solmaz (2010) on secondary school textbooks, it was found that the textbooks are far from scientific aspects, contradictory and inconsistent with linguistics.

According to these studies, teachers generally have negative opinions about the curriculum in terms of grammar teaching. Teachers mostly use textbooks as materials in their grammar lessons, but nevertheless, they do not find the texts in their textbooks sufficient for teaching grammar. When evaluated in terms of approaches and methods used in grammar lessons, teachers continue to use traditional methods and direct instruction method in their lessons even though they think that contemporary approaches and methods such as the constructivist approach are more effective. Our study is compatible with the findings of other studies in this field.

Recommendations developed according to the results obtained from the findings of the research are as follows:

1. Based on the finding that academic achievement and attitude towards the course differ from school level in the field of grammar, it is thought that it would be beneficial to diversify the Turkish language and literature curriculum to be applied in secondary education level schools according to the school level and therefore, according to students' linguistic readiness and interest and attitude towards the course. In this case, developing different language and literature curricula according to the school level and the qualifications of these schools will have positive benefits.

2. Based on the finding that teachers use textbooks as materials more in their lessons and most do not find the text in the textbooks sufficient for teaching grammar, it is recommended to make new arrangements for the texts chosen in the textbooks and to set the criterion for the appropriate grammar subject and to be able to exemplify the subject as necessary in terms of the texts chosen in the textbooks.

3. Based on the opinions of teachers about phonetics and morphology, grammar subjects that will be included in the curriculum should be arranged in accordance with the principle of teaching from the known to the unknown.

4. It is seen that teachers continue to use the direct instruction method, which is one of the traditional teaching methods, in grammar teaching. Therefore, it is thought that it is necessary to provide in-service training to our teachers on how to apply text-based grammar instruction in their lessons in order to carry out effective and functional grammar teaching that supports basic language skills in our schools. In this way, it can be provided that teachers can teach grammar subjects with a learner-centered discovery learning technique in accordance with the students' readiness levels and expectations of the students.

5. Considering the relationship between students' academic achievement in grammar and their attitudes towards the Turkish language and literature course, it can be recommended that students should be informed about the importance and necessity of learning grammar.

\section{References}

Akgül, E. (2010). Primary education II. grammar teaching problems in the level. Master Thesis.

Aslan, C. (2017). Teaching Turkish - Turkish language and literature with exemplary educational situations. Ankara: Anı Publishing.

Büyüköztürk, Ş. (2006). Data analysis handbook for social sciences. Ankara: Pegem Academy Publishing.

Büyüköztürk., Ş., Kılıç, Ç. E., Akgün, Ö. A., Karadeniz, Ş., \& Demirel, F. (2017). Scientific research methods (23rd ed.). Ankara: Pegem Academy.

Carkıt, C. (2013). Evaluation of grammar teaching process in secondary schools in terms of constructivist approach. Master Thesis.

Ceçen, M. Â. (2007). Text-based grammar teaching. Doctoral Thesis.

Ceçen., M. A., \& Aytaş, G. (2008). The effect of textual grammar teaching on eighth grade students' grammar success. Yüzüncï Yıl University Faculty of Education Journal, 5(1), 133-149.

Cemiloğlu, M. (2003). Turkish language and literature teaching. Istanbul: Alfa Publications.

Ciçek, S. (2006). Use of joke texts in mother tongue (Turkish) teaching. Master Thesis.

Derman, S. (2002). Use of fairy tale texts in mother tongue (Turkish) teaching. Master Thesis.

Derman., S. (2008). A research on the selection of texts in grammar teaching (7th grade). Doctoral Thesis.

Erdem, İ. (2007). A research on the problems of grammar teaching in primary education. Doctoral Thesis.

Ertekinoğlu, S. (2003). Examination of teachers' views on grammar teaching in Turkish lessons. Master Thesis.

Göçer, A. (2008). The use of analysis method in Turkish grammar teaching. Mustafa Kemal University Journal of Social Sciences Institute, 5(10), 101-119.

Güneş, F. (2017). Teaching Turkish: Approaches and models (5th ed.). Ankara: Pegem Academy.

Kanat, A. (2016). An investigation on the relationship between texts and grammar in elementary school second level Turkish textbooks. Master's Thesis.

Kavcar, C., Oğuzkan, F., \& Sever, S. (2005). Turkish teaching for Turkish and classroom teachers. Ankara: Engin Publishing.

MEB. (2018). Secondary education Turkish language and literature course (9th, 10th, 11 th and 12 th grades) curriculum. Retrieved from: http://mufredat.meb.gov.tr.

Menteş, B. K. (2004). Primary education II. tier VI. Effectiveness of active learning method in grammar teaching in classrooms. Master Thesis.

Mertens., D. M. (2019). Research and evaluation in education and psychology (5th ed.). California: Sage Publications.

Sağır, M. (2002). Grammar teaching in primary schools. Turkish Language, 1(601), 56-59.

Sentürk, H. (2008). Use of nursery rhymes in mother tongue (Turkish) teaching. Master Thesis.

Sever, S. (2000). Turkish teaching and full learning. Ankara: Anı Publishing. 
Simşek, R. (1983). Place of mother tongue in contemporary education [Special Issue]. Turkish language teaching (pp. 36-39). Ankara: Turkish Language Institute Publications.

Solmaz, M. (2010). An evaluation in terms of linguistics on secondary school grammar books. Doctoral Thesis.

Veyis, F. (2015). Attitude scale towards Turkish literature course: Validity and reliability study. Turkish Studies, 10(11), $1609-1620$.

Yakışan, O. (2017). Investigation of the effect of teaching strategy through the invention in grammar teaching in secondary schools on student success and permanence. Master Thesis.

Yıldırım, A., \& Simşek, H. (2011). Qualitative research methods in social sciences (8th ed.). Ankara: Seçkin Yayıncılık.

Yllmaz, O. (2018). Text-oriented grammar teaching in teaching Turkish as a foreign language. Master Thesis.

Yin, R. K. (2002). Case study research: Design ang methods (3rd ed.). Thousand Oaks: Sage Pbc.

Yin., R. K. (2009). Case study research: Design and methods (4th ed.). Thousand Oaks, CA: Sage. 